\title{
Удосконалена модель системи забезпечення безпеки польотів Повітряних Сил Збройних Сил України
}

\author{
Євген Гончаренко ${ }^{*}$; Станіслав Гончаренко ${ }^{\text {B }}$ \\ А Національний університет оборони України імені Івана Черняховського, пр-кт Повітрофлотський, 28, м. Київ, 03049, Україна \\ в Національний технічний університет України “Київський політехнічний інститут імені Ігоря Сікорського”, пр-кт Перемоги, 37, Київ, 03056, Україна
}

Received: October 05, 2020 | Revised: October 27, 2020 | Accepted: October 31, 2020

DOI: $10.33445 /$ sds.2020.10.5.9

\begin{abstract}
Анотація
Проведений аналіз стану аварійності в авіації Збройних Сил України свідчить про те, що ефективність забезпечення безпеки польотів знаходиться на низькому рівні та має тенденцію до подальшого погіршення Основною причиною, на думку авторів, $\epsilon$ застосування реагуючої стратегії для управління безпекою польотів. Метою даної публікації $\epsilon$ вирішення шляхів вдосконалення існуючої системи забезпечення безпеки польотів у статті авторами запропоновано удосконалення існуючої системи забезпечення безпеки польотів шляхом впровадження попереджуючої стратегії управління системою забезпечення безпеки польотів, в використанні інших показників та критерію оцінювання ефективності забезпечення безпеки польотів - прийнятного рівня, а також розрахунку ризику для безпеки польотів до початку застосування авіаційного комплексу.

Оцінювання ризику для безпечної експлуатації авіаційного комплексу здійснювати із застосуванням підходів нечіткої логіки. Застосування зазначених заходів в авіаційній діяльності авіації Збройних Сил України дозволить перейти від якісного до кількісного врахування ризику перед початком льотної експлуатації повітряних суден, що забезпечує завчасне прийнятяя управлінських рішень в системі забезпечення безпеки польотів.
\end{abstract}

Ключові слова: безпека польотів, система забезпечення безпеки польотів, ефективність забезпечення безпеки польотів, ризики для безпеки польотів.

\section{Постановка проблеми}

Протягом останніх років в авіації Збройних Сил (3С) України значно зросла кількість авіаційних подій $\left(N_{\mathrm{A}}\right)$ - основний показник аварійності. Так, із дванадцяти авіаційних подій за останні 10 років дев'ять (75\%) трапилось впродовж останніх п'яти років (мал. 1). Тільки за останні три роки трапилося 6 катастроф, що складає 50\% усіх подій 3 людськими жертвами за десятиріччя $[0,0,0]$.

Незважаючи на тенденції останніх десятиліть щодо погіршення загального стану всіх складових авіаційної системи ЗС України, які безпосередньо впливають на безпеку польотів (БзП) (що полягають у недостатньому ресурсному забезпеченні бойової підготовки, яка не дозволяла мати високий професійний рівень льотного складу, не забезпечувала достатню справність авіаційної техніки та засобів управління і забезпечення польотів, їх моральне та конструктивне старіння), причинами авіаційних подій, що відбулися у Збройних Силах України є людський фактор - $82 \%$ (порушення в організації польотів, недисциплінованість та недостатня професійна підготовка екіпажу, порушення під час ремонту авіаційної техніки), відмови повітряних суден - $13 \%$, причини не встановлені - $5 \%$.

\footnotetext{
* Corresponding author: ад'юнкт, e-mail: yev.v.honcharenko@gmail.com, ORCID: 0000-0001-7654-6083
} 




Малюнок 1 - Кількість авіаційних подій в авіації ЗС України

На даний час в авіації ЗС України використовується реагуюча (reactive) стратегія забезпечення БзП (ґрунтується на наукових роботах середини $80-x$ років минулого століття $[0,0,0])$, суть якої полягає у виявленні небезпечних факторів (ризиків для безпеки польотів) $Y_{i}$, їx аналізі та

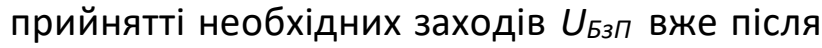
виникнення небезпечної події (відмови або порушення що призвели до авіаційної події (АП), серйозного інциденту (CI), інциденту).

Проведений аналіз стану аварійності в авіації ЗС України свідчить про те, що ефективність забезпечення безпеки польотів знаходиться на низькому рівні та має тенденцію до подальшого погіршення (від 5 до 15 АП на $10^{5}$ годин нальоту за останні 5 років).

\section{Аналіз останніх досліджень та публікацій}

У документах ICAО зазначається [7, 0, 0, 0, 0], що кожен суб'єкт авіаційної діяльності самостійно визначає методи, показники та критерії ефективності забезпечення БзП, відповідно до умов та особливостей льотної експлуатації авіаційної техніки.

Проблематика у сфері оцінювання ризиків для БзП розглядається багатьма ученими. Зокрема, у роботах $[0,0,0]$ розглядаються питання оцінювання ризику на рівні авіаційного підприємства цивільної авіації, у роботах $[0,0,0]$ пропонуються моделі оцінювання ризику безпеки польотів для цивільних повітряних суден. Про використання методів теорії нечіткої логіки для оцінювання ризиків для БзП зазначається у роботах $[0,0]$. Проте у відкритому доступі $\epsilon$ великою рідкістю публікація, що присвячені питанням оцінювання ризиків військових ПС $[0,0,0]$.

Нормативні документи з безпеки польотів військової авіації країн НАТО, зокрема Королівських ВПС Канади (Royal Canadian Air Force), зазначають проактивний підхід y вимогах до управління БзП (програма БзП Flight Safety Program) [0, 0, 0]. Треба зауважити, що впровадження передових підходів цивільної авіації до управління ризиками для БзП у Королівських ВПС Канади дає позитивні результати. Так, протягом останніх 50 років рівень аварійності канадських військових літаків на $10^{5}$ годин польоту знизився з 5,10 до $0,81[0]$, що $€$ одним 3 найкращих світових результатів.

\section{Постановка завдання}

Аналіз підходів що застосовуються до оцінювання ефективності забезпечення безпеки польотів в авіації ЗС України, У військово-повітряних силах деяких країн НАТО а також в цивільній авіації дає можливість побачити невирішену задачу - відсутність сучасних методів, що дозволяють поперед- жувати розвиток небезпечних факторів (ризиків для безпеки польотів) що призводять до авіаційних подій АП.

Таким чином, метою даної публікації $€$ вирішення шляхів вдосконалення існуючої системи забезпечення БзП. 


\section{Виклад основного матеріалу}

\section{1. Існуюча система забезпечення безпеки польотів}

Система забезпечення безпеки польотів (СЗ БзП) - це складова авіаційної системи, метою функціонування якої $€$ створення умов для безпечної авіаційної діяльності, яка включає наступні підсистеми:

- розслідування авіаційних подій, інцидентів, дослідження та аналіз їх причин;

- розробки рекомендацій по запобіганню авіаційних подій та інцидентів;

- контролю стану безпеки польотів та реалізації рекомендацій, який реалізується проведенням інспектувань та оцінюванням ефективності забезпечення БзП;

- розробки нормативних документів;

- інформаційного забезпечення.

Оскільки Повітряні Сили мають найпотужнішу авіаційну систему (AC) та службу безпеки польотів в усіх ЗС України, то в подальшому будемо розглядати систему забезпечення БзП Повітряних Сил (ПС) ЗС України. Система забезпечення БзП в авіації ПС ЗС України функціонує на чотирьох рівнях ієрархії: перший - рівень Міністерства оборони, другий - рівень Повітряних Сил, третій - рівень повітряних командувань (далі - ПвК) та четвертий - рівень авіаційних частин.

Структурно-функціональна схема системи забезпечення безпеки польотів (мал. 2) відображається набором елементів та їх інформаційних потоків, що виникають у визначений період часу.

На малюнку 2 позначено:

$U$-вектор управлінських рішень 3 безпеки польотів:


щодо організації льотної діяльності та забезпечення безпеки польотів;

$U_{E Б}$ - щомісячний Експрес-бюлетень 3 безпеки польотів;

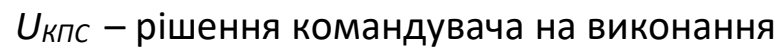
бойових завдань авіацією або проведення польотів (затвердження плану польотів та перельотів на добу);

$U_{\text {Бзп }}$ - заходи із забезпечення безпеки польотів;

$U_{K}$ - рішення командира авіаційної частини на польоти;

$Y_{i}-$ небезпечні фактори (НФ) що впливають на БзП, які виявлено за результатами розслідувань небезпечних подій та інспекційних перевірок з безпеки польотів;

$Y_{\text {АКі. }}$ - результат застосування $i$-го АК;



$\chi_{j}$ - статистичні данні з безпеки польотів, за певний період часу.

На кожному рівні СЗ БзП проводяться схожі за змістом, проте різні за масштабом заходи з забезпечення БзП. Управлінські


зменшення впливу на авіаційну систему (АC) дії небезпечних факторів (НФ) $Y_{i}$, що виявляються в ході розслідувань небезпечних подій та інспекційних перевірок. На рівні Міністерства оборони розслідуються авіаційні події (катастрофи та аварії). Командуванням ПС розслідуються серйозні інциденти, а причини інцидентів досліджують на рівні ПвК. Далі проводиться дослідження та аналіз виявлених НФ що дозволяє здійснення вироблення шляхів зменшення впливу НФ на $A C$ та відпрацювання відповідних рекомендацій


що регламентують льотну діяльність та забезпечення БзП здійснюється на рівні Міністерства оборони. В командування ПС реалізується підсистема інформаційного забезпечення. Щомісячно відпрацьовуються Експрес-бюлетені 3 аналізу стану БзП в державній авіації України, в яких доводяться

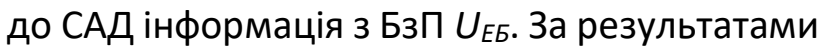
оцінювання ефективності забезпечення БзП

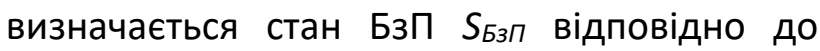

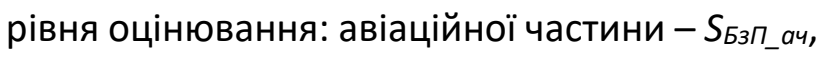

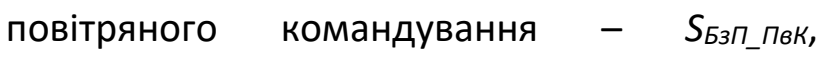

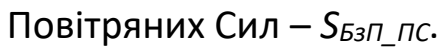




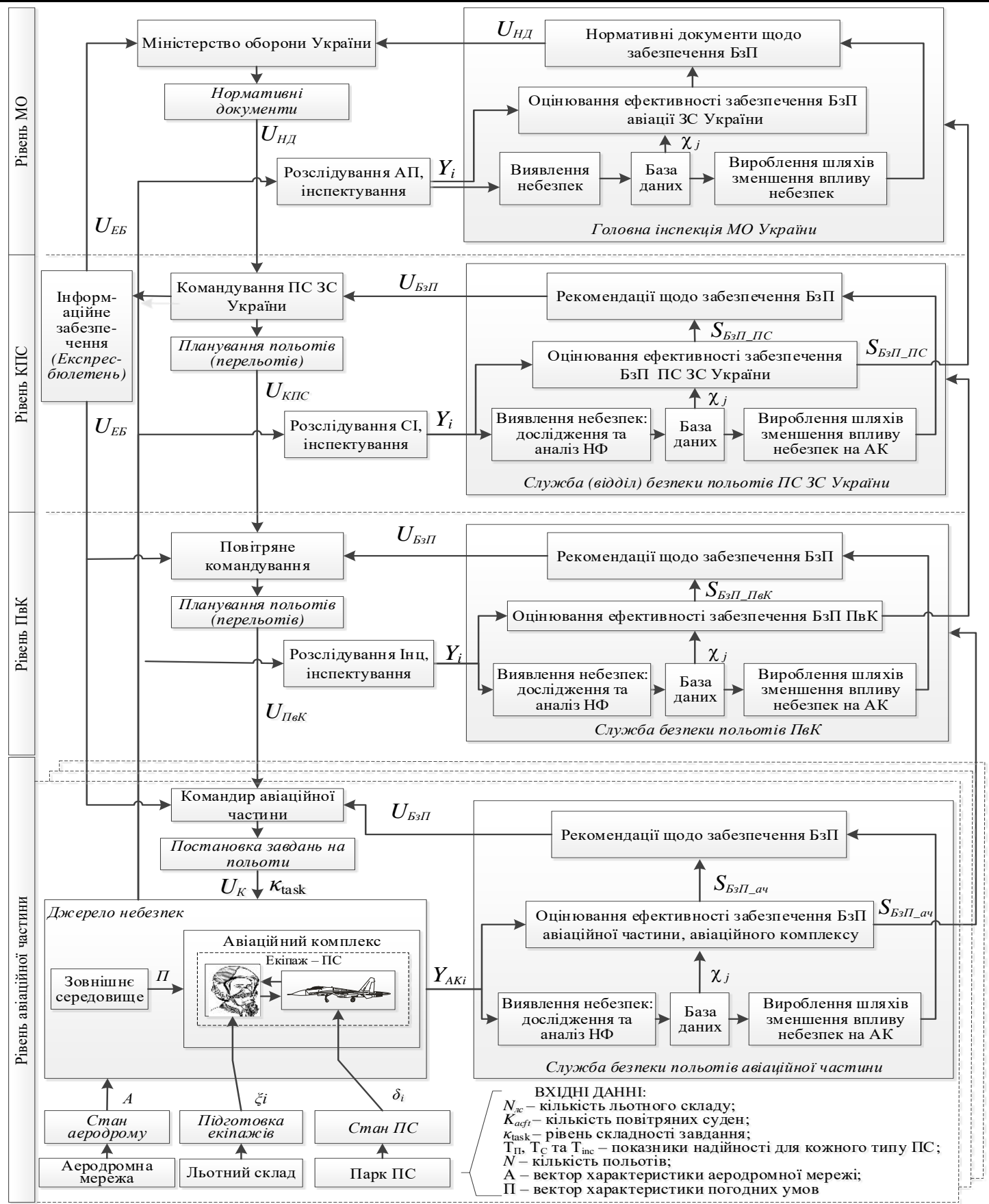

Малюнок 2 - Структурно-функціональна схема системи забезпечення безпеки польотів Повітряних Сил Збройних Сил України

Критерієм оцінки стану БзП $є$ усунення конкретних небезпечних факторів, їх відсутність або значне зниження інтенсивності їх прояву. Оскільки результатом прояву небезпечних факторів завжди $\epsilon$ небезпечна подія, то і критерієм оцінки $€$ значення інтенсивності небезпечних подій за певний інтервал часу. Тому критерій оцінки стану БзП може бути записаний як

$S_{\text {БзП }}:\left\{n_{\mathrm{A \Pi}}^{Л \Phi}, \lambda_{\text {АП }} \rightarrow \min , \quad T_{\text {інц }}, \mathrm{T}_{\text {iнц }}^{Л \Phi}, T_{\mathrm{CI}} \rightarrow \max \right\}(1)$ де $n_{A \Pi}^{Л \Phi}-$ кількість АП що пов'язані 3 людським фактором за певний період;

$\lambda_{\text {АП }}$ кількість АП на $10^{5}$ годин нальоту;

$T_{\text {іни }}$ - наліт на 1 інцидент;

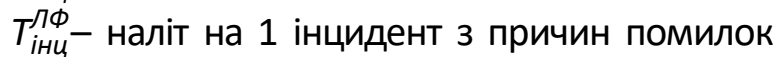
(порушень) особового складу;

$T_{C I}$ - наліт на 1 серйозний інцидент.

Методи оцінювання стану БзП які на даний час застосовуються в ПС ЗС України мають наступні недоліки: 
не можливо визначити тенденції ефективності забезпечення БзП,

не враховується обсяг задач що виконала авіаційна система (для методу інспектувань),

не враховується кількості подій (небезпечних факторів, інцидентів, серйозних інцидентів, аварій та катастроф, що не пов'язані з людським фактором;

не визначають моменту вироблення управлінських рішень з метою своєчасного втручання в роботу авіаційної системи для усунення НФ.

2. Удосконалена система забезпечення безпеки польотів

В цивільній авіації та авіації збройних сил передових країн НАТО використовується попереджуюча (proactive) стратегія забезпечення БзП (ґрунтується на сучасних наукових роботах XXI століття), суть якої полягає в завчасній профілактиці, яка здійснюється шляхом виявлення небезпечних факторів (ризику) та вжиття заходів по зменшенню ризику перш, ніж трапиться будь-яка небезпечна подія. Застосування науково обґрунтованих методів управління факторами ризику $\epsilon$ центральною складовою попереджуючої стратегії управління БзП [0].

Для впровадження попереджуючої стратегії пропонується в існуючий системі забезпечення БзП ПС ЗС України удосконалити “підсистему контролю стану безпеки польотів та реалізації рекомендацій". Для цього пропонується (мал. 3):

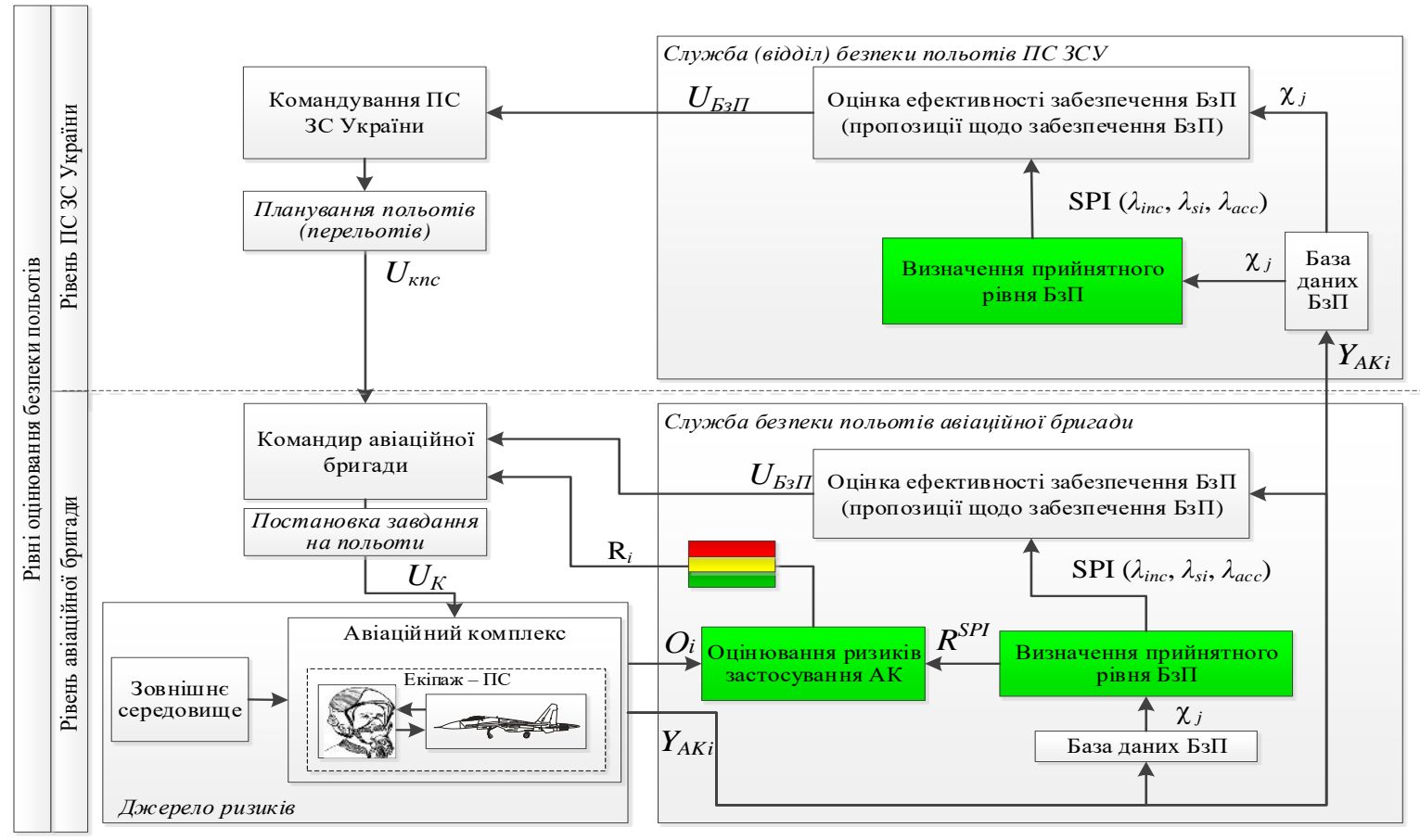

Малюнок 3 - Структурно-функціональна схема удосконаленої системи забезпечення безпеки польотів Повітряних Сил Збройних Сил України

застосування у якості критерія оцінювання ефективності забезпечення БзП суб'єкта авіаційної діяльності значення прийнятного рівня БзП (Safety Performance Indicator - SPI), що забезпечує завчасного прийняття управлінських рішень в системі забезпечення БзП;

здійснювати

завчасне

кількісне оцінювання ризику для безпечної експлуатації авіаційного комплексу (або ризику для БзП) $R_{i}$, що дозволить перейти від якісного до кількісного врахування ризику перед початком льотної експлуатації повітряних суден, та забезпечує виявляння моменту необхідності втручання в управління експлуатацією авіаційної техніки.

Додані елементи удосконаленої системи забезпечення БзП лише доповнюють існуючу СЗ БзП, не виключаючи наявних елементів та зв'язків. 
Для оцінювання якості функціонування системи забезпечення БзП в державній авіації застосовують поняття “стан БзП" а в цивільній авіації, що керується нормами IKAO ефективність забезпечення БзП.

В межах цього дослідження будемо вважати ці поняття синонімами. Оскільки під ефективністю забезпечення БзП $E_{5 з}$ вважається досягнутий (авіацією ПС ЗС України) рівень БзП, що визначається показниками ефективності забезпечення БзП
$[0,0]$ в залежності від прийнятного рівня цих показників.

Таким чином, якщо річ іде про існуючу СЗ БзП, для оцінювання якої використовують показники та критерії, що зазначені в (1), то

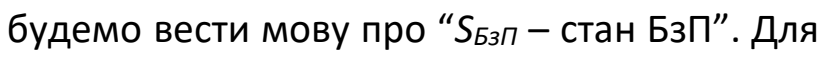
оцінювання ефективності забезпечення БзП удосконаленої СЗ БзП користуються показниками (2), критерієм (3) та терміном “ $E_{Б з п}$ - ефективність забезпечення БзП".

$$
\lambda_{\text {acc }}=\frac{n_{\text {acc }}}{t_{\Sigma}} \cdot 10^{5}, \lambda_{s i}=\frac{n_{s i}}{t_{\Sigma}} \cdot 10^{3}, \lambda_{\text {inc }}=\frac{n_{\text {inc }}}{t_{\Sigma}} \cdot 10^{2}, \lambda_{\text {inc } 1}=\frac{n_{\text {inc } 1}}{t_{\Sigma}} \cdot 10^{5}, \lambda_{\text {inc } 2}=\frac{n_{\text {inc } 2}}{t_{\Sigma}} \cdot 10^{2},
$$

де $\lambda_{\text {Aп }}$ інтенсивність АП - кількість авіаційних подій за 100000 годин нальоту;

$\lambda_{c i}-$ інтенсивність $\mathrm{Cl}$ - кількість серйозних інцидентів за 1000 годин нальоту;

$\lambda_{\text {інц }}$ - інтенсивність інцидентів - кількість інцидентів за 100 годин нальоту;

$\lambda_{\text {ннц1 }}$ - інтенсивність інцидентів 1 групи - кількість інцидентів 1 групи причин, за 100 годин нальоту;

$\lambda_{\text {інц2 }}$ - інтенсивність інцидентів 2 групи - кількість інцидентів 2 групи причин за 100 годин нальоту;

$n_{c /}-$ число зареєстрованих $\mathrm{Cl}$ за певний період;

$n_{\text {інц }}-$ число зареєстрованих інцидентів за певний період,

$n_{\text {інц1 }}$ - число зареєстрованих інцидентів 1 групи за певний період;

$n_{\text {iнц2 }}-$ число зареєстрованих інцидентів 2 групи за певний період.

В удосконаленій СЗ БзП здійснюється визначення значень прийнятного рівня показників БзП САД. Ефективність забезпечення БзП САД оцінюється 3 урахуванням значень абсолютних показників БзП $\chi_{j}$ в залежності від їх причин $j=1 . . .15-$ кількість причини згідно класифікатора [0] або відносних показників $\lambda$ та їх прийнятного рівня. Критерій ефективності забезпечення БзП за визначений інтервал часу буде записаний як

$$
\mathrm{E}_{\text {БзП }}:\left\{\lambda_{\mathrm{A \Pi}} \leq \lambda_{\mathrm{A} \Pi}^{S P I}, \lambda_{\mathrm{ci}} \leq \lambda_{\mathrm{ci}}^{S P I}, \lambda_{\mathrm{iнц}} \leq \lambda_{\mathrm{iнц}}^{S P I}\right\}
$$

де $\lambda_{A \Pi}^{S P I}, \lambda_{c i}^{S P I}, \lambda_{\text {iни }}^{S P I}$ - “прийнятні" значення відносних показників ефективності забезпечення БзП.

Часткова методика визначення прийнятного рівня безпеки польотів суб'єкта авіаційної діяльності докладно розглядається у п.3.1.1.

Критерії (1, 3) застосовуються для оцінювання ефективності забезпечення БзП вже по результатам функціонування АС. Для прогнозування результатів функціонування системи забезпечення БзП проведено формалізацію процесів, що відбуваються в СЗ БзП ПС ЗС України.

Авіаційний комплекс (АК) $\epsilon$ головною складовою частиною $\mathrm{AC}$, що включає етап експлуатації повітряного судна та забезпечує отримання вихідних даний для дослідження всієї системи забезпечення БзП. Саме в АК реалізуються (проявляються) всі небезпеки (ризики), як внутрішні, так і під впливом зовнішнього середовища - зовнішні. Вся робота із забезпечення БзП пов'язана 3 виявленням і зменшенням ризиків для БзП.

До складу АК входять (мал. 4):

управління АК (командир авіаційної бригади, його заступники, штаб);

засоби та фахівці групи керівництва польотами;

система "екіпаж - ПС";

засоби та фахівці видів забезпечення польотів (аеродромно-технічне забезпе- 
чення, забезпечення аеронавігаційною інформацією, зв'язок та радіотехнічне забезпечення, інженерно-авіаційне забезпечення, медичне забезпечення, метеорологічне забезпечення, орнітологічне забезпечення, морально-психологічне забезпечення, пошуково-рятувальне забезпечення, радіо- локаційне забезпечення, штурманське забезпечення, об'єктивний контроль польотів) [0].

В межах цього дослідження будемо розглядати АК як основний елемент $\mathrm{AC}$, та вплив небезпечних факторів (ризиків) на його функціонування.

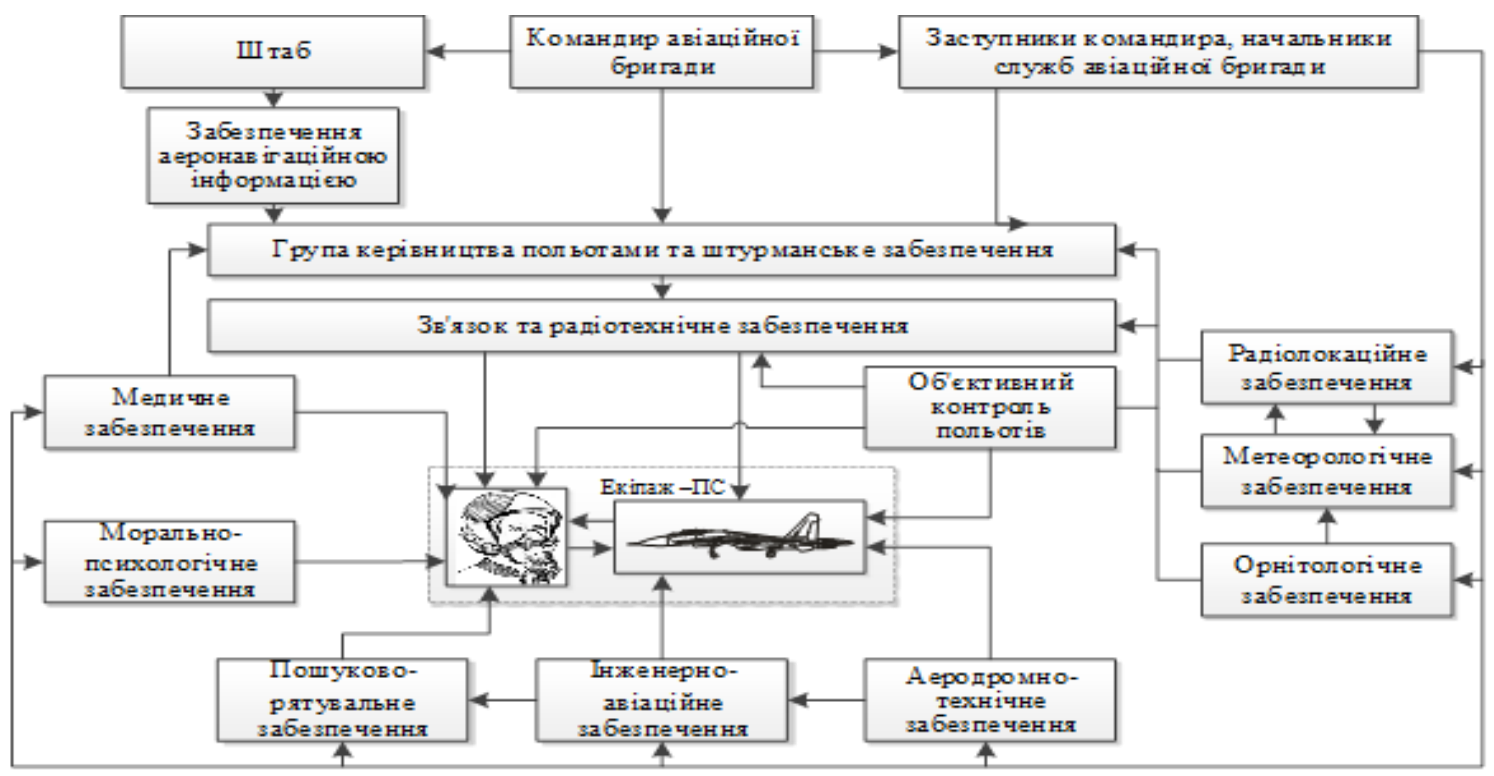

Малюнок 4 - Структурно-функціональна схема авіаційного комплексу

Оскільки В ЗС України діє принцип єдиноначальності, то загальний вплив на функціонування АК здійснює командир (авіаційної частини). На етапі прийняття рішення на проведення польотів командир авіаційної частини керується наказами

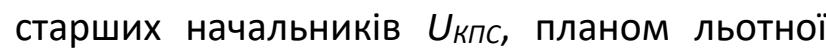
підготовки $U_{\text {План, }}$ оцінює обстановку, заслуховує i аналізує пропозиції своїх заступників, начальників служб, командирів авіаційних підрозділів, командирів частин (підрозділів) забезпечення польотів $U_{5 з п}[0]$. Рішення командира авіаційної частини на польоти $U_{K}$ формалізується як функція

$$
U_{K}=f\left(U_{\text {КПС }}, U_{\text {План }}, U_{\text {БзП }}\right),
$$

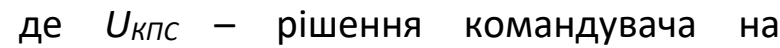
виконання бойових завдань авіацією або проведення польотів (затвердження плану польотів та перельотів на добу);

$U_{\text {План }}$ - заходи льотної підготовки, що передбачені планом,

$U_{\text {Бзп }}$ - заходи із забезпечення безпеки польотів, що залежать від складності завдання $\kappa_{\text {task, }}$ вимог нормативних документів $U_{\text {нд, }}$ вимог 3 БзП від Командування ПС $U_{E Б}$ а також від вихідних даних про стан АК

$$
U_{\text {БзП }}=f\left(\kappa_{\text {task }}, U_{\text {нд }}, U_{E Б}, O\right),
$$

де $O$ - вектор вихідних даних про стан АК (за доповідями начальників служб та командирів підрозділів авіаційної частини), що залежать від рівня готовності екіпажу до виконання поставленого завдання $\xi$; стану повітряного судна $\delta$, зовнішніх факторів $\phi$ та виражається

$$
O_{i}=f\left(\xi_{i}, \delta_{i}, \phi_{i}\right)
$$

де $\xi_{i}$ - рівень готовності $i$-го екіпажу до виконання поставленого завдання;

$\delta_{i}-$ стан $i$-го повітряного судна;

$\phi$ - зовнішні фактори, що впливають на результат застосування $i$-го АК.

Оскільки в залежності від завдань польоти ПС поділяються на: бойові польоти (польоти за призначенням), спеціальні польоти, навчально-тренувальні польоти (ознайомлю- 
вальні, показові, вивізні, контрольні, тренувальні, залікові та методичні) та навчальні (ознайомлювальні, показові, вивізні, контрольні, тренувальні, залікові, екзаменаційні) [0], то для об'єднання понять, що пов'язані з управлінськими рішеннями в залежності від завдань, у подальшому $U_{\kappa п c}$ та

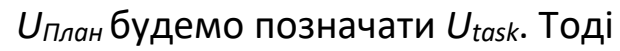

$$
U_{K}=f\left(U_{\text {task }}, U_{\text {БзП }}\right) \text {. }
$$

Слід зауважити, що ефективність забезпечення БзП ПС ЗС України складається з результатів усіх польотів, що були виконані в усіх авіаційних частинах ПС ЗС України за певний інтервал часу (місяць, квартал, рік, тощо)

$$
E_{\text {БзП }}=\sum_{i=1}^{N} Y_{A K i},
$$

де $Y_{\text {Акі. }}$ - результат застосування i-го АК. $Y_{A K}=\left\{y_{б п}, y_{і н и} y_{c i}, y_{A п}\right\}-$ безпечне завершення польоту Убп, в результаті польоту обліковано

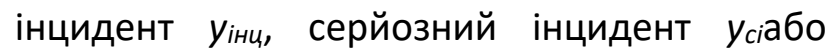
трапилась авіаційна подія уАп;

$N$ - загальна кількість польотів (застосувань АК).

Система забезпечення БзП працює на виявлення та усунення тих ризиків, які можна передбачити, тому для оцінювання ефективності забезпечення безпеки польотів будемо вважати, що результат польоту напряму залежить від рішення командира. Тоді вираз (6) прийме вигляд

$$
E_{\text {БзП }}=\sum_{i=1}^{N} f\left(U_{K i}\right),
$$

або враховуючи $(6,7)$

$E_{\text {БзП }}=\sum_{i=1}^{N} U_{\text {task } i} \times U_{\text {НД }} \times U_{\text {ЕБ }} \times U_{\text {НД }} \times \kappa_{\text {task } i} \times \xi_{i} \times \delta_{i} \times \phi_{i}(10)$

Статистика свідчить, що менше 2\% авіаційних подій 3 3,5 тисячі катастроф і аварій, що мали місце в авіації Збройних Сил в період з 1945 по 1990 роки, відбулося через недостатньо глибокого опрацювання або суперечливості положень нормативних документів. У той же час, більш ніж 1,5 тисячі авіаційних подій (майже 43\%) сталося через недотримання або навмисного порушення особовим складом встановлених норм і правил польотів [0]. Тому найбільшу значимість в забезпеченні БзП має робота щодо контролю за проведенням та забезпеченням польотів. Рекомендації 3


ПвК мають загальний характер і напряму не впливають на результат польоту.

Тільки підсистема контролю стану безпеки польотів та реалізації рекомендацій, здатна оперативно впливати на роботу системи забезпечення БзП. Оперативність досягається проведенням інспектувань функціонування AC та оцінюванням ефективності забезпечення БзП. Тому для спрощення побудови моделі на кінцевий результат польоту вплив підсистем розслідування авіаційних подій та інцидентів $Y_{i}$, розробки

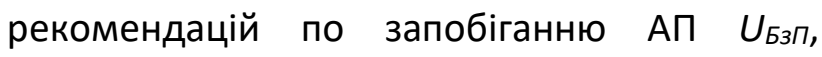
розробки нормативних документів $U_{H д}$, інформаційного забезпечення $U_{E 5}$ будемо вважати значно меншим, ніж вплив підсистеми оцінюванням ефективності забезпечення БзП, та виведемо в обмеження

$$
E_{\text {Бз }}=\sum_{i=1}^{N} \kappa_{\text {task } i} \times \xi_{i} \times \delta_{i} \times \phi_{i} .
$$

Складність завдання (польоту) Ktask визначається як коефіцієнт, значення якого визначається експертами та знаходяться в межах $(0,1]$. Де 1 найскладніше завдання, i наближається до 0 - найпростіше, проте ніколи це значення не може дорівнювати 0 оскільки виконання польоту це складна (рискована) задача.

\section{Висновки}

Автором формалізовано існуючу систему забезпечення безпеки польотів ПС ЗС України. Високий рівень аварійності у ПС ЗС України за останні 5 років (від 5 до 15,4 АП на $10^{5}$ годин нальоту) $€$ наслідком недосконалих методів оцінювання та застосування реагуючої стратегії при управлінні безпекою польотів які не дозволяють адекватно та завчасно реагувати на існуючі та потенційні ризики для БзП.

Автором удосконалено модель існуючої системи забезпечення безпеки польотів ПС ЗС України. Удосконалення полягає: 
в можливості впровадження попереджуючої стратегії управління системою забезпечення БзП ПС ЗС України;

В використанні в якості показників ефективності забезпечення безпеки польотів інтенсивність небезпечних подій;

в застосуванні нового для ПС ЗС України критерія оцінювання ефективності забезпечення БзП- прийнятного рівня БзП;

в забезпеченні безпечної експлуатації повітряних суден шляхом розрахунку ризику для БзП до початку виконання польоту.

Оцінювання ефективності забезпечення БзП авіаційних комплексів ПС ЗС України слід розглядати на рівні суб'єктів авіаційної діяльності (ПС ЗС України, Повітряного командування, авіаційної бригади).

Визначення прийнятного

рівня забезпечення БзП САД доцільно проводити на рівні авіаційної частини, що експлуатує однотипні ПС та на рівні ПС ЗС України, де $\epsilon$ можливість узагальнення статистичних даних цілком за вид зС України.
Оцінювання ризику для безпечної експлуатації авіаційного комплексу здійснювати із застосуванням підходів нечіткої логіки. Теорія нечітких множин є однією 3 найбільш розроблених у інженерному відношенні математичних теорій, що призначені для формалізації невизначеної інформації для вирішенні аналітичних задач.

Застосування зазначених заходів в авіаційній діяльності ПС ЗС України дозволить перейти від якісного до кількісного врахування ризику перед початком льотної експлуатації повітряних суден, що забезпечує завчасне прийняття управлінських рішень в системі забезпечення БзП.

Напрямком подальшого дослідження може бути розгляд питань застосування методів Fuzzy Logic для визначення ефективності забезпечення БзП. Крім того, визначення значень шкали ризику для оцінювання рівня небезпеки застосування авіаційного комплексу.

\section{Список використаних джерел}

1. Інформаційний випуск з авіаційних подій та інцидентів за період 1992-2001 років, МОУ ВПС ЗСУ, 2002. - 30 с.

2. Інформаційні випуски з авіаційних подій та інцидентів за період 2002-2017 роки, МОУ ПС ЗСУ.

3. Гончаренко Є. Культура безпеки польотів державної авіації України. Наука і оборона, 2019, № 1, с. 36-39. DOI: 10.33099/26181614-2019-6-1-36-39.

4. Жулев В. И., Иванов В. С. Безопасность полетов: (теория и анализ). - М: Транспорт, 1986. - 224c.

5. Безопасность полетов: Учебник для ВУЗов / Р.В. Сакач, Б.В. Зубков, М.Ф. Давиденко и др.; Под ред. Р.В.Сакача. - М.: Транспорт, 1989. - 239 с.

6. Котельніков Г.Н., Лихоманенко В.А. Безпека польотів літальних апаратів. К., 2004, 230с.

7. Safety Management - Annex 19 to the Convention on International Civil Aviation, 2nd edition. Montreal: ICAO, 2016.

8. Doc 9859-AN/474, Safety Management Manual, 4th edition. Montreal: ICAO 2017.
9. Международная организация гражданской авиации. Рабочий документ. Тринадцатая аэронавигационная конференция. Монреаль, Канада, 9-19 октября 2018 года. Пункт 6 повестки дня. Организационные вопросы в области безопасности полетов. AN-Conf/13-WP/116 19/9/18.

10. Международная организация гражданской авиации. Рабочий документ. Тринадцатая аэронавигационная конференция. Монреаль, Канада, 9-19 октября 2018 года. Пункт 6.2 повестки дня. Реализация принципов управления безопасностью полетов. AN-Conf/13-WP/28 19/06/18.

11. Международная организация гражданской авиации. Рабочий документ. Тринадцатая аэронавигационная конференция. Монреаль, Канада, 9-19 октября 2018 года. Пункт 8 повестки дня. Проблемы, возникающие в области безопасности полетов. AN-Conf/13-WP/46 24/8/18.

12. Шаров В. Д. Методология управления риском безопасности полетов на уровне авиапредприятия. Диссертация на 
соискание ученой степени доктора технических наук. - Москва, МГТУГА, 2016. $-285 \mathrm{c}$.

13. Лушкин А. М. Методика оценивания уровня безопасности полетов по совокупности авиационных событий. Научный весник МГУ ГА, 2010, № 162 p.125-130.

14. Netjasov F., Janic M. A Review of Research on Risk and Safety Modeling in Civil Aviation. Journal of Air Transport Management.Vol.14, issue 4, 2008, Pp. 213-220

15. Luxh $\varnothing$ j, J. Coit, D. Modeling Low Probability /High Consequence Events: An Aviation Safety Risk Model. Reliability and Maintainability Sympocium. [E-journal]. 2006. Pages 215-221. DOI: 10.1109/RAMS.2006. 1677377.

16. Cheng, C. Kuo, Y. Shyur, H. Implementation of a flight operations risk assessment system and identification of critical risk factors. Journal of Scientia Iranica. [E-journal] Vol. 21. 2014. Pages 2387-2398. ISSN: 2345-3605.

17. Gerd Els. Safety Assessment Methodologies and Application for the Deployment of Laptops in Production System Environment. [Електронний ресурс] // - Режим доступу: htps://www.giac.org/paper/gsec/4219/safetyassessments-methodologies-applica-tiondeployment-laptops-productionsystem/106765 (21.01.2019.)

18. Sami Vuokko. Safety Risk Modelling of Flight Planning in Commercial Operation of Performance Class B Aeroplanes. [Master's Thecis]. Aalto Univercity. 2016. 76 p.

19. Honcharenko Y., Martyniuk O., Radko O., Open'ko P. The method of proactive risk assessment for flight safety based on the rate of dangerous events //Advances in Military Technology Vol. 15, No. 2, 2020. p. 365-377. DOI: $10.3849 /$ aimt.01424.

20. Honcharenko Y., Martyniuk O., Radko O., Blyskun O., Kolomiiets Yu., Bilokur M. Flight safety fuzzy risk assessment for combat aviation system // 2020 IEEE International Conference on Advanced Trends in Information Theory ATIT / Kyiv / Ukraine. in press.

21. Барзилович Е. Ю., Савенков М. В. Статистические методы оценки состояния авиационной техники. М.: Транспорт, 1987. $-240 \mathrm{c}$.

22. Мартинюк, О. Р., Радько, О. В., Гончаренко, Є.В. Оцінювання ризику в системі забезпечення безпеки польотів державної авіації України // Сучасні інформаційні технології у сфері безпеки та оборони. - К.: НУОУ, 2019. - № 1(34). - C. 155-160. DOI: 10.33099/2311-7249/2019-34-1-155-160

23. A-GA-135-001/AA-001 Flight Safety for the Canadian Armed Forces, New Edition, 14 Dec 2018, [Електронний ресурс] - Режим доступу: <http://www.rcafarc.forces.gc.ca/en/flight-safety/manuals.page>, (2020-0510).

24. NATO STANAG 3102, Flight safety cooperation in common ground/air space.

25. Airworthiness Investigation Manual A-GA-135003/AG-001.

26. The Royal Canadian Air Force highlights historical lows of flight safety інціdents during the Air Forces Flight Safety Committee (Europe) meeting, [Електронний ресурс] Режим доступу: <https://www.canada.ca/en/department-national-defence/news/ 2019/07/the-royal-canadian-air-forceh-ighlights-historical-lows-of-flight-safety-інціdents -during-the-air-forces-flight-safety-committeeeurope-meeting.html>, (2020-05-10).

27. Повітряний Кодекс України: Указ Президента України № 3393-VI від 19.05.2011.

28. Правила розслідування авіаційних подій та інцидентів в авіації Збройних Сил України, наказ Міністра оборони України від 19.05.2010 №256, зареєстрований в Міністерстві юстиції України 14.06.2010 за №386/17681, [Електронний ресурс] - Режим доступу: https://zakon.-rada.gov.ua/laws/ show/z0386-10, (2020-05-10).

29. Про затвердження правил виконання польотів в державній авіації України, наказ Міністерства оборони України від 05.01.2015 № 2 .

30. Методика расследования авиационных происшествий и инцидентов. - М.: Воениздат, 1995 г. 
Усовершенствованная модель системы обеспечения безопасности полетов Воздушных Сил Вооруженных Сил Украины

\author{
Евгений Гончаренко * А; Станислав Гончаренко ${ }^{\text {B }}$ \\ *Corresponding author: адъюнкт, e-mail: yev.v.honcharenko@gmail.com, ORCID: 0000-0001-7654-6083

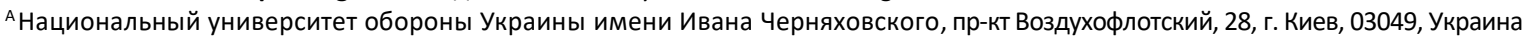

 \\ пр-кт Победы, 37, Киев, 03056, Украина
}

\begin{abstract}
Аннотация
Проведенный анализ состояния аварийности в авиации Вооруженных Сил Украины свидетельствует о том, что эффективность обеспечения безопасности полетов находится на низком уровне и имеет тенденцию к дальнейшему ухудшению Основной причиной, по мнению авторов, является применение реагирующей стратегии для управления безопасностью полетов. Целью данной публикации является решение путей совершенствования существующей системы обеспечения безопасности полетов В статье авторами предложено усовершенствование существующей системы обеспечения безопасности полетов путем внедрения упреждающей стратегии управления системой обеспечения безопасности полетов, в использовании других показателей и критерия оценивания эффективности обеспечения безопасности полетов - приемлемого уровня, а также расчета риска для безопасности полетов до начала применения авиационного комплекса.

Оценка риска для безопасной эксплуатации авиационного комплекса осуществлять с применением подходов нечеткой логики. Применение указанных мер в авиационной деятельности авиации Вооруженных Сил Украины позволит перейти от качественного к количественному учету риска перед началом летной эксплуатации воздушных судов, обеспечивает заблаговременное принятие управленческих решений в системе обеспечения безопасности полетов.
\end{abstract}

Ключевые слова: безопасность полетов, система обеспечения безопасности полетов, эффективность обеспечения безопасности полетов, риски для безопасности полетов.

\title{
Improved model of the Ukrainian Air Force flight safety system
}

\author{
Yevhen Honcharenko * A; Stanislav Honcharenko ${ }^{B}$ \\ *Corresponding author: PhD student, e-mail: yev.v.honcharenko@gmail.com, ORCID: 0000-0001-7654-6083 \\ A National Defence University of Ukraine named after Ivan Cherniakhovskyi, 28, Povitroflotskyi Ave, Kyiv, 03049, Ukraine \\ B National Technical University of Ukraine "Igor Sikorsky Kyiv Polytechnic Institute", 37, Peremohy Ave, Kyiv, 03056, Ukraine
}

\begin{abstract}
The analysis of the state of accidents in aviation of the Armed Forces of Ukraine indicates that the effectiveness of ensuring flight safety is at a low level and tends to further deteriorate. The main reason, according to the authors, is the use of a reactive strategy for flight safety management. The purpose of this publication is to address ways to improve the existing safety management system. In the article, the authors propose to improve the existing flight safety system by implementing a proactive strategy for managing the flight safety system, using other indicators and a criterion for assessing the effectiveness of flight safety - an acceptable level, as well as calculating the safety risk before the start of the aviation complex.

The risk assessment for the safe operation of the aviation complex should be carried out using fuzzy logic approaches. The application of these measures in the aviation activities of the aviation of the Armed Forces of Ukraine will make it possible to move from qualitative to
\end{abstract}


quantitative accounting of risk before the start of flight operation of aircraft, and ensures the advance adoption of management decisions in the flight safety system.

Keywords: flight safety, flight safety system, flight safety performance, risks for flight safety.

\section{References}

1. [Informatsiinyi vypusk $z$ aviatsiinykh podii ta intsydentiv za period 1992-2001], (Ukr.) VPS ZSU, 2002. $30 \mathrm{p}$.

2. [Informatsiinyi vypusk $z$ aviatsiinykh podii ta intsydentiv za period 2002-2017], (Ukr.) VPS ZSU, 2018. 42 p.

3. Honcharenko, Y. [Flight Safety Culture of the State Aviation of Ukraine] (Ukr.). Science and Defence, 2019, no. 1, p. 36-39. DOI: 10.33099/2618-1614-2019-6-1-36-39.

4. Zhulev, V.I. and Ivanov, V.S. [Flight Safety of Aircraft] (Rus.). Moscow: Transport, 1986. 224 p. ISBN 978-5-45-834929-1.

5. Sakach R. V., Zubkov B. V., Davidenko M. F. [Bezopasnost poletov: Uchebnik dlya VUZov]. (Rus.). Moscow: Transport, 1989. 239 s.

6. Kotelnikov H. N., Lykhomanenko V. A. [Bezpeka polotiv litalnykh aparativ]. (Ukr.). Kyiv, 2004, 230 p.

7. Safety Management - Annex 19 to the Convention on International Civil Aviation, 2nd edition. Montreal: ICAO, 2016.

8. Doc 9859-AN/474, Safety Management Manual, 4th edition. Montreal: ICAO 2017.

9. International Civil Aviation Organization. Working paper. Thirteenth Air Navigation Conference. Montreal, Canada, October 919, 2018. Item 6 of the agenda. Organizational issues in the field of flight safety. AN-Conf/13-WP/116 19/9/18.

10. International Civil Aviation Organization. Working paper. Thirteenth Air Navigation Conference. Montreal, Canada, October 919, 2018. Item 6.2 of the daily agenda. Implementation of safety management principles. AN-Conf/13-WP/28 19/06/18.

11. International Civil Aviation Organization. Working paper. Thirteenth Air Navigation Conference. Montreal, Canada, October 919,2018 . Item 8 of the agenda. Safety issues. AN-Conf/13-WP/46 24/8/18.

12. Sharov V. D. [Metodologiya upravleniya riskom bezopasnosti poletov na urovne aviapredpriyatiya] (Rus.). Dissertation for the degree of Doctor of Technical Sciences. Moscow, MGTUGA, 2016. 285 p.

13. Lushkin A.M. [Metodika otsenivaniya urovnya bezopasnosti poletov po sovokupnosti aviatsionnyih sobyitiy] (Rus.). Nauchnyiy vesnik MGU GA, 2010, \# 162 p. 125-130.

14. Netjasov F., Janic M. A Review of Research on Risk and Safety Modeling in Civil Aviation. Journal of Air Transport Management.Vol.14, issue 4, 2008, Pp. 213-220

15. Luxhøj, J. Coit, D. Modeling Low Probability/High Consequence Events: An Aviation Safety Risk Model. Reliability and Maintainability Sympocium. [E-journal]. 2006. Pages 215-221. DOI: 10.1109/RAMS.2006.1677377.

16. Cheng, C. Kuo, Y. Shyur, H. Implementation of a flight operations risk assessment system and identification of critical risk factors. Journal of Scientia Iranica. [E-journal] Vol. 21. 2014. P. 2387-2398.

17. Gerd Els. Safety Assessment Methodologies and Application for the Deployment of Laptops in Production System Environment. Available from: ttps://www.giac.org/paper/ gsec/4219/safety-assessments-methodo logies-applica-tion-deployment-laptopsproduction-system/106765.

18. Sami Vuokko. Safety Risk Modelling of Flight Planning in Commercial Operation of Performance Class B Aeroplanes. [Master's Thecis]. Aalto Univercity. 2016. 76 p.

19. Honcharenko Y., Martyniuk O., Radko O., Open'ko P. The method of proactive risk assessment for flight safety based on the rate of dangerous events //Advances in Military Technology Vol. 15, No. 2, 2020. p. 365-377. DOI: 10.3849/aimt.01424.

20. Honcharenko Y., Martyniuk O., Radko O., Blyskun O., Kolomiiets Yu., Bilokur M. Flight safety fuzzy risk assessment for combat 
aviation system // 2020 IEEE International Conference on Advanced Trends in Information Theory ATIT / Kyiv / Ukraine. in press.

21. Barzilovich E.Yu., Savenkov M.V. [Statisticheskie metodyi otsenki sostoyaniya aviatsionnoy tehniki] (Rus.). Moscow: Transport, 1987. 240 p.

22. Martyniuk, O., Radko, O. and Honcharenko, Y. [The Risk Assessment in the State Aviation Safety Performance System] (Ukr.). Modern Information Technologies in the Sphere of Security and Defence, 2019, vol. 34, no. 1 , p. 155-160. DOI: 10.33099/2311-7249/2019-34-1-155-160T.

23. A-GA-135-001/AA-001 Flight Safety for the Canadian Armed Forces, New Edition, 14 Dec 2018, Available from: http://www.rcafarc. forces.gc.ca-/en/flight-safety/manuals. page.

24. NATO STANAG 3102, Flight safety cooperation in common ground/air space.

25. Airworthiness Investigation Manual A-GA135-003/AG-001.

26. The Royal Canadian Air Force highlights historical lows of flight safety intsidents during the Air Forces Flight Safety Committee
(Europe) meeting, Available from: https://www.canada.ca-/en/departmentnational-defence/news/2019/07/the-royalcanadian-air-forceh-igh-lights-historicallows-of-flight-safety-inцidents-during-theair-forces-flight-safety-committee-europemeeting.html.

27. Air Code of Ukraine. (Ukr.). Available from: https://zakon.rada.gov.ua/laws/show/339317\#Textt

28. Rules for the investigation of aviation accidents and incidents in the aviation of the Armed Forces of Ukraine, Order of the Minister of Defense of Ukraine 19.05.2010 N256. (Ukr.). Available from: https://zakon.rada.gov.ua/laws/show/z038 6-10.

29. [Pro zatverdzhennia pravyl vykonannia polotiv $v$ derzhavnii aviatsii Ukrainy, nakaz Mini-sterstva oborony Ukrainy vid 05.01.2015 № 2] (Ukr.). Available from https://zakon.rada.gov.ua/laws/show/z0082 $-15 \#$ Text

30. [Metodika rassledovaniya aviatsionnyih proisshestviy i intsidentov]. (Rus.). Moscow: Voenizdat, 1995. 